\title{
Buffer Capacity Curves of Green Tea Extracts Using a Personal Computer with Numerically Treated Online Software
}

\author{
Hideki YAMANO ${ }^{1}$ and Kinjiro MIYAGAWA ${ }^{2, *}$ \\ ${ }^{1}$ Faculty of Education, Kagawa University, 1-1, Saiwaicho, Takamatsu, Kagawa 760, Japan \\ ${ }^{2}$ Division of Clinical Nutrition, Suzuka University of Medical Science and Technology, I001-1, Kishioka, Suzuka, Mie 510-02, Japan
}

Received August 14, 1996

\begin{abstract}
A trial device was made to measure the buffer capacity of foods using a personal computer. This device differs from the conventional analog-treated buffer capacity apparatus, so that the buffer capacity of dilute samples, such as $10^{-4} \mathrm{~mol} l^{-1}$, can be measured with high stability. The buffer capacity of water is subtracted automatically from that of the sample. The output signal is automatically converted to the buffer capacity value, so that the data obtained can be easily treated. Thus buffer capacity measurement becomes an easy determination.
\end{abstract}

Keywords: buffer capacity, personal computer, green tea

The buffer capacity of a solution is defined as the reciprocal of the slope $(\mathrm{d}[\mathrm{B}] / \mathrm{dpH})$ of the titration curve with a strong base [B]. This is a fundamental concept in solution chemistry (Perrin \& Dempsey, 1974). Some of its applications have been utilized in food science (Tsuji, 1982a, 1983; Tsuji \& Takeo, 1983; Miyagawa \& Namba, 1988; Miyagawa et al., 1989). Conventionally, the buffer capacity has been measured using an analog circuit type of device (Tsuji, 1982b, c) or from calculation of the titration curve (Gordon, 1982). The former method, however, has a problem of precision in the differential circuit, so that the titration must be done at a fairly rapid rate with a high concentration of base, and hence the response of a $\mathrm{pH}$ electrode cannot follow. In the latter case, calculation from the titration curve to obtain a satisfactory buffer capacity curve requires too many data points to be practical.

Gordon (1982) reported the buffer capacities of wines using a main-frame computer such as IBM system/360. However, this is inconvenient for routine work.

This report is undertaken to measure the buffer capacity of solutions by a simple method using a personal computer and attempts an application for food study.

\section{Materials and Methods}

Almost all commercial pH meters have an analog output terminal for $\pm 0.7 \mathrm{~V}$ which is linearly equivalent to $\mathrm{pH} 0$ to 14 , and in the high quality $\mathrm{pH}$ meters, $\mathrm{pH}$ output is also converted to a digital signal, which can be accepted directly by a computer.

This study used an analog type of $\mathrm{pH}$ meter (F-12, HORIBA Co., Kyoto) connected with a 12 bit A/D converter (DAS-9801BPC, Micro Science Co., Tokyo).

Titration was carried out using an automatic buret with potassium hydroxide (concentration, $c_{\mathrm{B}}=0.1 \mathrm{~mol} l^{-1}$ ), at

\footnotetext{
*To whom correspondence should be addressed.
}

constant titration speed $\left(\mathrm{d} V_{\mathrm{B}} / \mathrm{d} t=0.01-0.2 \mathrm{ml} \mathrm{min}^{-1}\right)$.

A 32 bit microcomputer (PC-9801BX2, NEC, Tokyo) and BASIC language for the program were used.

The tea was used "Sencha" produced in the Sayama area in Saitama Prefecture, Japan.

The catechins and theanine used were commercial pure grade (over 98\%) from Mitsui-norin Co., Ltd., Tokyo, and other chemicals used were reagent grade.

Data treatment for $\mathrm{pH}$ and titration volume (i) The value of $\mathrm{pH}$ at time $t$ is expressed as $\mathrm{pH}(t)=(1 / n) \Sigma \mathrm{pH}$, that is, $\mathrm{A} / \mathrm{D}$ conversion is done 1,000 times $(n=1,000)$ each second and averaged. Titration volume at time $t, V_{\mathrm{B}}(t)$, is calculated as $V_{\mathrm{B}}(t)=(\mathrm{d} V / \mathrm{d} t) t$, and hence the volume for each second is $\Delta V=1 \times\left(\mathrm{d} V_{\mathrm{B}} / \mathrm{d} t\right)$.

(ii) $\mathrm{pH}$ is divided into $1 / 100(\Delta \mathrm{pH}=0.01)$ and expressed as $\overline{\mathrm{pH}}$. The $V_{\mathrm{B}}(t)$ is collected by the same units and is averaged, $\bar{V}_{\mathrm{B}}(\overline{\mathrm{pH}})=(1 / m) \sum V_{\mathrm{B}}(t)$, as shown in Fig. 1 .

(iii) When the volume data do not show a pronounced $\mathrm{pH}$ change, five data points that are not zero, $\bar{V}_{\mathrm{B}}(\overline{\mathrm{pH}}) \neq 0$, are fitted to a quadratic function. The approximate value in this interval, $V_{\text {calc }}$, and the respective weight factor, $w$, are then calculated. This calculation is applied to all $\mathrm{pH}$ intervals, and values are averaged and expressed as titration volume, $\bar{V}_{\text {calc }}(\overline{\mathrm{pH}})$, that is, $\bar{V}_{\text {calc }}(\overline{\mathrm{pH}})=\left(1 / \sum w\right) \sum\left(w V_{\text {calc }}\right)$, as shown in Fig. 2.

(iv) The differentiation of $\bar{V}_{\text {calc }}(\overline{\mathrm{pH}})$ to $\mathrm{pH}, \mathrm{d} \bar{V}_{\text {calc }}(\overline{\mathrm{pH}}) /$ $\mathrm{d} \overline{\mathrm{pH}}$, is obtained from the tangent at the center point (Savitzky \& Golay, 1964) when the volume, $\bar{V}_{\text {calc }}(\overline{\mathrm{pH}})$, is fitted to the quadratic function for an interval of $0.1 \mathrm{pH}$ as shown in Fig. 3, and this value is applied in turn to all $\mathrm{pH}$ intervals.

Using the values of $\mathrm{pH}, \mathrm{pH} \equiv \overline{\mathrm{pH}}$, at each $\Delta \mathrm{pH}$, the titration volume, $V_{\mathrm{B}}(\mathrm{pH}) \equiv \bar{V}_{\text {calc }}(\overline{\mathrm{pH}})$, and its differentiation, $\left\{\mathrm{d} V_{\mathrm{B}}(\mathrm{pH})\right\} / \mathrm{dpH} \equiv \mathrm{d} \bar{V}_{\text {calc }}(\overline{\mathrm{pH}}) / \mathrm{d} \overline{\mathrm{pH}}$, obtained from the above steps (i) to (iv).

The calculation of buffer capacity We consider the 


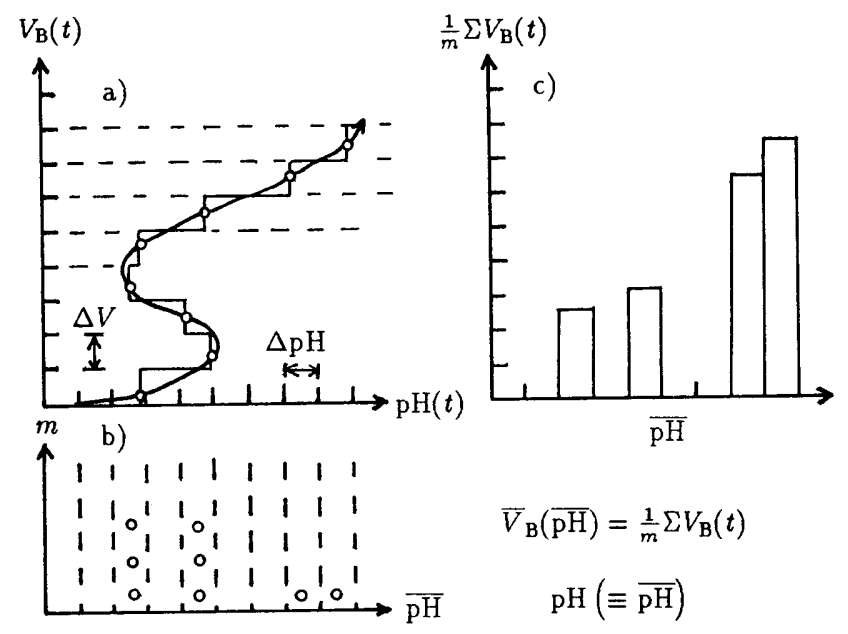

Fig. 1. $\mathrm{pH}$ resolution of titration data. a) Volume and $\mathrm{pH}$ data at each second, b) frequency of titration volume at each $\mathrm{pH}$, and c) averaged titration volume at each $\mathrm{pH}$.

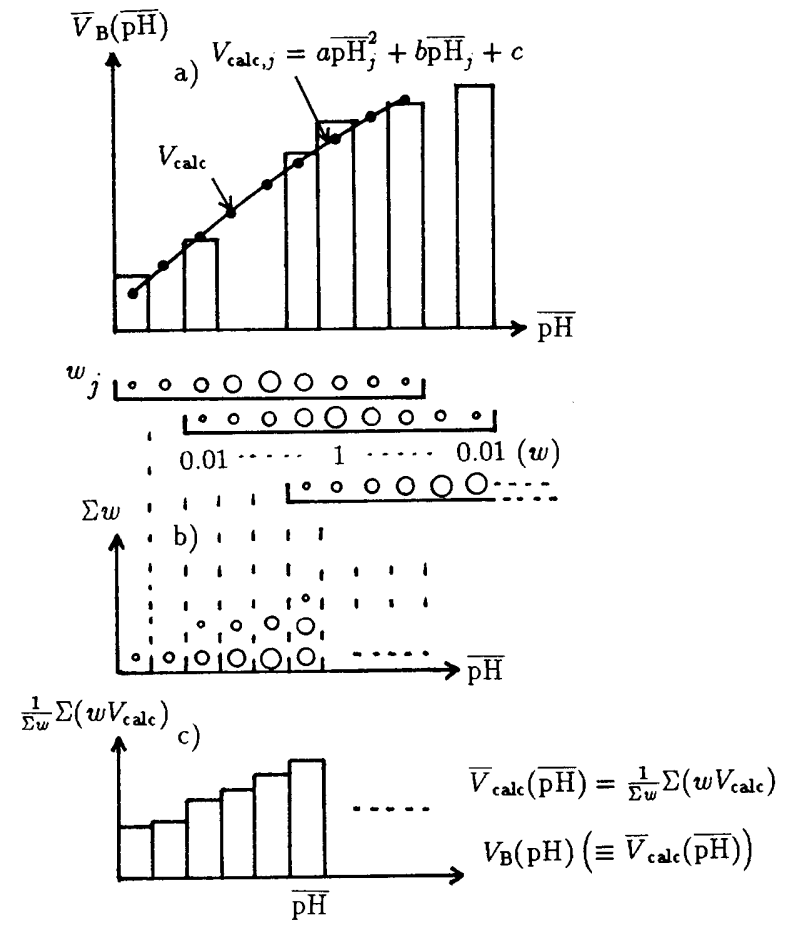

Fig. 2. Interpolation of data that was fitted to the quadratic function. a) Volume and $\mathrm{pH}$ data for fitting, b) sum of weight factor at each $\mathrm{pH}$, and c) average of fitted volume at each $\mathrm{pH}$

equilibrium of a monobasic weak acid $\left(\mathrm{HA} \rightleftharpoons \mathrm{H}^{+}+\mathrm{A}^{-}\right)$ and its titration with a strong base $(\mathrm{BOH})$ (Barrow, 1974; Perrin \& Dempsey, 1974; Tsuji, 1982c). The initial concentration and initial volume of the weak acid are given as $[\mathrm{AH}]+$ $\left[\mathrm{A}^{+}\right]=c_{\mathrm{A}}$ and $V_{\mathrm{A}}$, respectively. The initial concentration and the volume of the strong acid to obtain the starting $\mathrm{pH}$ of the sample for titration are regarded as $\left[\mathrm{A}_{\mathrm{S}}{ }^{-}\right]=c_{\mathrm{S}}$ and $V_{\mathrm{S}}$, and the initial concentration of the strong base and its titration volume to some $\mathrm{pH}$ are $\left[\mathrm{B}^{+}\right]=c_{\mathrm{B}}$ and $V_{\mathrm{B}}(\mathrm{pH})$, respectively. From the principle of electric neutrality, the practical dissociation constant of the weak $\operatorname{acid}\left(K_{\mathrm{a}}{ }^{\prime}\right)$ and the ion product of water $\left(K_{\mathrm{W}}\right)$, the following Eqs. 1 to 3 can be applied.

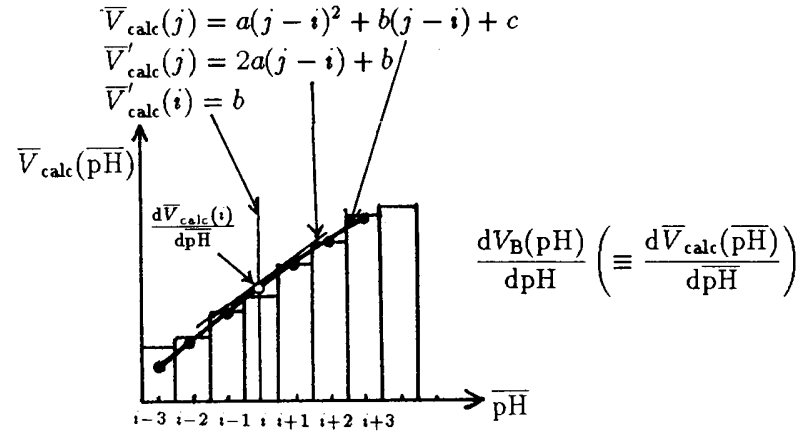

Fig. 3. Differentiation of center point by fitting the quadratic function

$$
\begin{gathered}
{\left[\mathrm{H}^{+}\right]+\left[\mathrm{B}^{+}\right]=\left[\mathrm{OH}^{-}\right]+\left[\mathrm{A}^{-}\right]+\left[\mathrm{A}_{\mathrm{S}}{ }^{-}\right]} \\
\frac{\left[\mathrm{H}^{+}\right]\left[\mathrm{A}^{-}\right]}{[\mathrm{HA}]}=K_{\mathrm{a}}{ }^{\prime} \\
{\left[\mathrm{H}^{+}\right]\left[\mathrm{OH}^{-}\right]=K_{\mathrm{W}}}
\end{gathered}
$$

When Eqs. 1 to 3 were connected, Eq. 4 can be obtained. The concentration of the strong base, the weak acid and the strong acid are $c_{\mathrm{B}} V_{\mathrm{B}}(\mathrm{pH}) /\left\{V_{\mathrm{A}}+V_{\mathrm{S}}+V_{\mathrm{B}}(\mathrm{pH})\right\}, c_{\mathrm{A}} V_{\mathrm{A}} /\left\{V_{\mathrm{A}}+\right.$ $\left.V_{\mathrm{S}}+V_{\mathrm{B}}(\mathrm{pH})\right\}$, and $c_{\mathrm{S}} V_{\mathrm{S}} /\left\{V_{\mathrm{A}}+V_{\mathrm{S}}+V_{\mathrm{B}}(\mathrm{pH})\right\}$, respectively, and these values are substituted in Eq. 4 to give Eq. 5. We obtained Eq. 6 by multiplying both sides of Eq. 5 by $\left\{V_{\mathrm{A}}+\right.$ $\left.V_{\mathrm{S}}+V_{\mathrm{B}}(\mathrm{pH})\right\} / V_{\mathrm{A}}$ and transposing.

$$
\begin{aligned}
& {\left[\mathrm{H}^{+}\right]+\left[\mathrm{B}^{+}\right]=\frac{K_{\mathrm{W}}}{\left[\mathrm{H}^{+}\right]}+\frac{c_{\mathrm{A}} K_{\mathrm{a}}^{\prime}}{K_{\mathrm{a}}+\left[\mathrm{H}^{+}\right]}+\left[\mathrm{A}_{\mathrm{S}}{ }^{-}\right]} \\
& {\left[\mathrm{H}^{+}\right]+\frac{c_{\mathrm{B}} V_{\mathrm{B}}(\mathrm{pH})}{V_{\mathrm{A}}+V_{\mathrm{S}}+V_{\mathrm{B}}(\mathrm{pH})}=\frac{K_{\mathrm{W}}}{\left[\mathrm{H}^{+}\right]}+} \\
& \quad \frac{c_{\mathrm{A}} V_{\mathrm{A}}}{V_{\mathrm{A}}+V_{\mathrm{S}}+V_{\mathrm{B}}(\mathrm{pH})} \cdot \frac{K_{\mathrm{a}}^{\prime}}{K_{\mathrm{a}}^{\prime}+\left[\mathrm{H}^{+}\right]}+\frac{c_{\mathrm{S}} V_{\mathrm{S}}}{V_{\mathrm{A}}+V_{\mathrm{S}}+V_{\mathrm{B}}(\mathrm{pH})} \\
& c_{\mathrm{B}} \frac{V_{\mathrm{B}}(\mathrm{pH})}{V_{\mathrm{A}}}=\frac{c_{\mathrm{A}} K_{\mathrm{a}}^{\prime}}{K_{\mathrm{a}}{ }^{\prime}+\left[\mathrm{H}^{+}\right]}+ \\
& \frac{V_{\mathrm{A}}+V_{\mathrm{S}}+V_{\mathrm{B}}(\mathrm{pH})}{V_{\mathrm{A}}}\left(\frac{K_{\mathrm{W}}}{\left[\mathrm{H}^{+}\right]}-\left[\mathrm{H}^{+}\right]\right)+c_{\mathrm{S}} \frac{V_{\mathrm{S}}}{V_{\mathrm{A}}}
\end{aligned}
$$

Equation 6 is differentiated with respect to $\left[\mathrm{H}^{+}\right]$to give Eq. 7. Because $d p H=(-1 / 2.303) \mathrm{d} \ln \left[\mathrm{H}^{+}\right]=\left(-1 / 2.303\left[\mathrm{H}^{+}\right]\right)$ $\mathrm{d}\left[\mathrm{H}^{+}\right]$, Eq. 7 can be changed to Eq. 8. By definition, $\left[\mathrm{H}^{+}\right]=$ $10^{-\mathrm{pH}}, K_{\mathrm{W}}=10^{-\mathrm{p} K_{\mathrm{w}}}$, and $K_{\mathrm{a}}{ }^{\prime}=10^{-\mathrm{p} K_{\mathrm{a}^{\prime}}} ;$ Eq. 8 can be written as Eq. 9.

$$
\begin{aligned}
& \frac{c_{\mathrm{B}}}{V_{\mathrm{A}}} \cdot \frac{\mathrm{d} V_{\mathrm{B}}(\mathrm{pH})}{\mathrm{d}\left[\mathrm{H}^{+}\right]}=-\frac{c_{\mathrm{A}} K_{\mathrm{a}}{ }^{\prime}}{\left(K_{\mathrm{a}}{ }^{\prime}+\left[\mathrm{H}^{+}\right]\right)^{2}} \\
& +\frac{1}{V_{\mathrm{A}}}\left(\frac{K_{\mathrm{W}}}{\left[\mathrm{H}^{+}\right]}-\left[\mathrm{H}^{+}\right]\right) \frac{\mathrm{d} V_{\mathrm{B}}(\mathrm{pH})}{\mathrm{d}\left[\mathrm{H}^{+}\right]} \\
& +\frac{V_{\mathrm{A}}+V_{\mathrm{S}}+V_{\mathrm{B}}(\mathrm{pH})}{V_{\mathrm{A}}}\left(\frac{-K_{\mathrm{W}}}{\left[\mathrm{H}^{+}\right]^{2}}-1\right) \\
& \frac{c_{\mathrm{B}}}{V_{\mathrm{A}}} \cdot \frac{\mathrm{d} V_{\mathrm{B}}(\mathrm{pH})}{\mathrm{dpH}}=\frac{2.303 c_{\mathrm{A}} K_{\mathrm{a}}^{\prime}\left[\mathrm{H}^{+}\right]}{\left(K_{\mathrm{a}}^{\prime}+\left[\mathrm{H}^{+}\right]\right)^{2}} \\
& +\frac{1}{V_{\mathrm{A}}}\left(\frac{K_{\mathrm{W}}}{\left[\mathrm{H}^{+}\right]}-\left[\mathrm{H}^{+}\right]\right) \frac{\mathrm{d} V_{\mathrm{B}}(\mathrm{pH})}{\mathrm{dpH}} \\
& +2.303 \frac{V_{\mathrm{A}}+V_{\mathrm{S}}+V_{\mathrm{B}}(\mathrm{pH})}{V_{\mathrm{A}}}\left(\frac{K_{\mathrm{W}}}{\left[\mathrm{H}^{+}\right]}+\left[\mathrm{H}^{+}\right]\right) \\
& \frac{c_{\mathrm{B}}}{V_{\mathrm{A}}} \cdot \frac{\mathrm{d} V_{\mathrm{B}}(\mathrm{pH})}{\mathrm{dpH}}=\frac{2.303 c_{\mathrm{A}}}{\left(1+10^{\mathrm{p} K \mathrm{a}^{\prime}-\mathrm{pH}}\right)\left(1+10^{\mathrm{pH}-\mathrm{p} K_{\mathrm{a}^{\prime}}}\right)} \\
& +\frac{1}{V_{\mathrm{A}}}\left(10^{\mathrm{pH}-\mathrm{p} K_{\mathrm{w}}}-10^{-\mathrm{pH}}\right) \frac{\mathrm{d} V_{\mathrm{B}}(\mathrm{pH})}{\mathrm{dpH}}
\end{aligned}
$$




$$
+2.303 \frac{V_{\mathrm{A}}+V_{\mathrm{S}}+V_{\mathrm{B}}(\mathrm{pH})}{V_{\mathrm{A}}}\left(10^{\mathrm{pH}-\mathrm{pK}{ }_{\mathrm{w}}}+10^{-\mathrm{pH}}\right)
$$

In Eq. 9, the second and the third terms on the right side give the buffer capacity of water $\left(\beta_{\mathrm{W}}\right)$. The left side of Eq. 9 shows the buffer capacity of the weak acid and includes the buffer capacity of water. Accordingly, when $\beta-\beta_{\mathrm{w}}$ is plotted against $\mathrm{pH}$, the buffer capacity curve of the weak acid can be obtained.

We calculated $K_{\mathrm{W}}$ at temperature, $T$, from Eq. 10 (Barrow, 1974) using the values for the standard enthalpy change of the ionization of water, $\Delta H^{0}=55.90 \mathrm{~kJ} \mathrm{~mol}^{-1}$, and the heat capacity of water, $C_{P}{ }^{0}=-224.1 \mathrm{~J} \mathrm{~mol}^{-1} \mathrm{~K}^{-1}$ (Barrow, 1974; Chem. Soc. Japan, 1982), where $T_{0}=298.15 \mathrm{~K}, K_{\mathrm{W}}{ }^{0}=1 \times 10^{-14}$, and $R=8.3145 \mathrm{~J} \mathrm{~K}^{-1} \mathrm{~mol}^{-1}$.

$$
\begin{aligned}
\ln K_{\mathrm{W}}= & \frac{\Delta H^{0}-C_{P}{ }^{0} T_{0}}{R}\left(\frac{1}{T_{0}}-\frac{1}{T}\right)+\frac{C_{P}{ }^{0}}{R} \ln \frac{T}{T_{0}} \\
& +\ln K_{\mathrm{W}}{ }^{0}
\end{aligned}
$$

From the first term on the right side of Eq. 9, simulation curves can be obtained.

Component analysis is made by multivariate analysis using the non-negative least squaring method (Leggett, 1977). To solve the algorithm, the non-linear programming method described by Lawson \& Hanson (1974) is applied.

The work steps of the software and the schematic diagram of the hardware for the trial device are shown in Figs. 4 and 5 , respectively.

\section{Results and Discussion}

To confirm the reasonability of the theoretical equation,

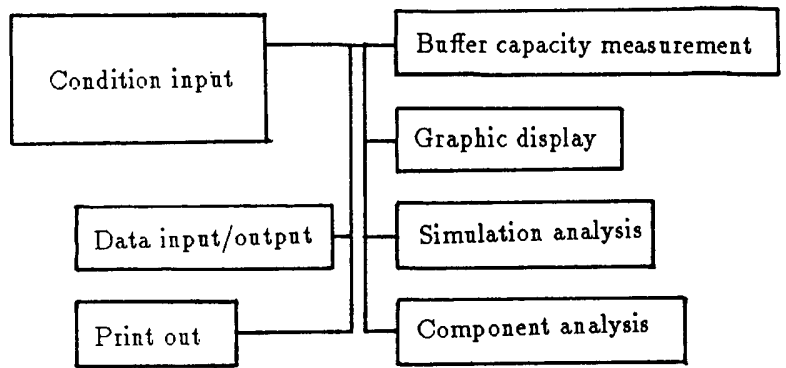

Fig. 4. Work steps for measurement of buffer capacity curves by personal computer. the buffer capacity curve of a concentrated acetic acid solution was measured. Figures 6 and 7 show the buffer capacity curves, $\beta$ and $\beta-\beta_{\mathrm{w}}$ of acetic acid solutions at different concentrations from 0 to $8 \times 10^{-4} \mathrm{~mol} l^{-1}$, respectively. The thermodynamic dissociation constant, $\mathrm{p} K_{\mathrm{a}}$, of acetic acid (Barrow, 1974; Chem. Soc. Japan, 1982) is 4.76, so that the buffer capacity would be maximum at $\mathrm{pH} 4.7$. Figure 6 does not show the maximum value. However, when $\beta_{\mathrm{w}}$ is subtracted from $\beta$, Fig. 7 , the maximum value is nearly at $\mathrm{pH}$

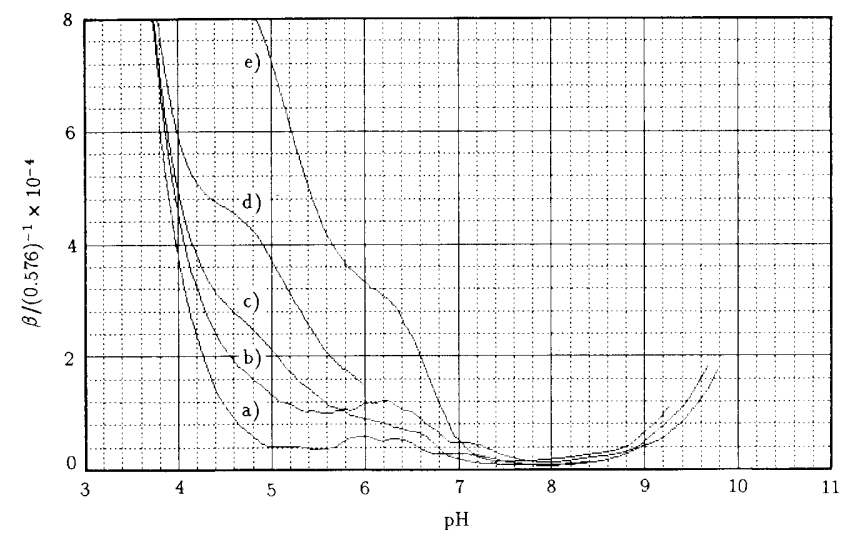

Fig. 6. Buffer capacity curves of acetic acid solutions without subtraction of buffer capacity of water. Acetic acid concentration: a) none, b) $0.1 \mathrm{mmol} l^{-1}$, c) $0.2 \mathrm{mmol} l^{-1}$, d) $0.4 \mathrm{mmol} l^{-1}$, and e) $0.8 \mathrm{mmol} l^{-1}$.

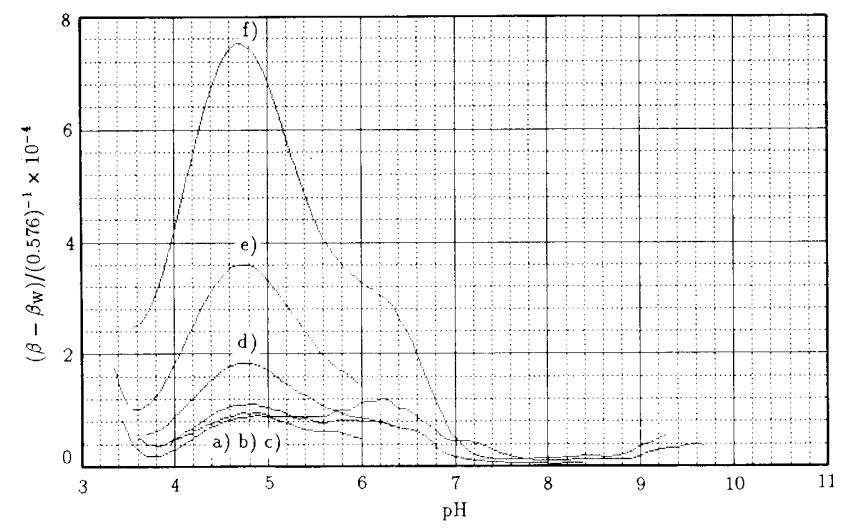

Fig. 7. Buffer capacity curves of acetic acid solutions after subtraction of the buffer capacity of water. Acetic acid concentrations: a, b, and c) $0.1 \mathrm{mmol} l^{-1}$, d) $0.2 \mathrm{mmol} l^{-1}$, e) $0.4 \mathrm{mmol} l^{-1}$, and f) $0.8 \mathrm{mmol} l^{-1}$.

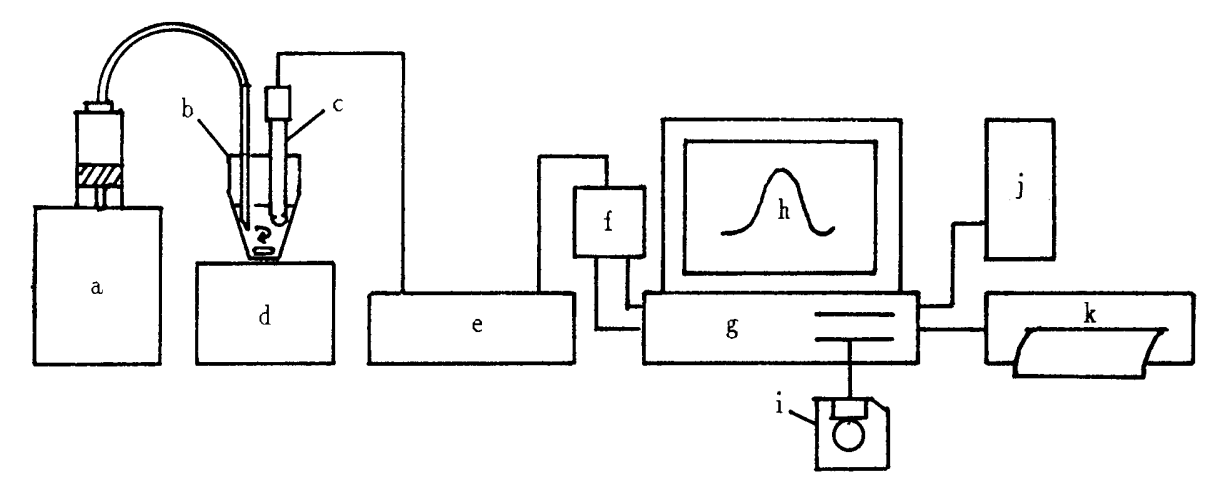

Fig. 5. Schematic diagram of the trial device for measurement of buffer capacity curves by personal computer. a) Digital auto buret, b) measuring vessel, c) hydrogen electrode, d) magnetic stirrer, e) pH-meter, f) A/D converter card, g) personal computer, h) display monitor, i) floppy disk unit, j) hard disk unit, and k) plotter. 


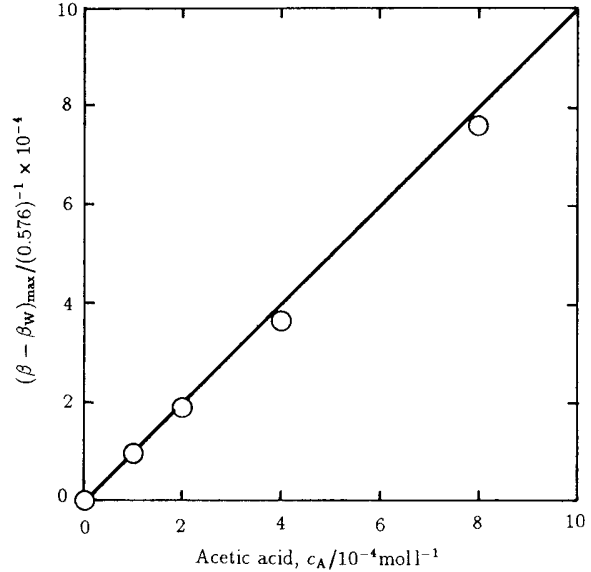

Fig. 8. Relation between peaks of buffer capacity curves and concentration of acetic acid.

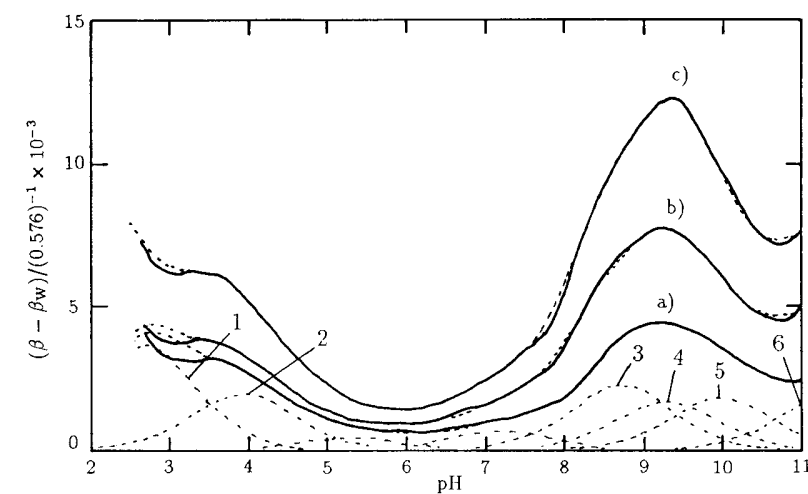

Fig. 9. Buffer capacity curves of green tea extracts. One gram (reduced to dry state) of green tea was extracted with $50 \mathrm{ml}$ of water at $60^{\circ} \mathrm{C}$. Extracted time: a) $30 \mathrm{~s}$, b) $5 \mathrm{~min}$, and c) $10 \mathrm{~min}$. Solid lines are the observed curves and dotted lines are fitted curves by multivariate analysis and component curves $(1,2,3$, 4,5 , and 6) of the fitting curve for extraction for $30 \mathrm{~s}$

Table 1. Chemical analysis of the green tea.

\begin{tabular}{clc}
\hline Sample & Constituents & \% on dry basis \\
\hline Tea extract $^{(a)}$ & Catechins & 7.20 \\
& Theanine & 2.02 \\
& Glutamic acid & 0.16 \\
& Aspartic acid & 0.18 \\
& Arginine & 0.43 \\
Green leaves $^{b)}$ & Caffeine & 2.33 \\
& Oxalic acid & 1.2 \\
& Citric acid & $0.3-1.8$ \\
\hline
\end{tabular}

${ }^{a)}$ Nakagawa et al. (1981), ${ }^{b}$ Kato (1993).

4.7. The shoulder at $\mathrm{pH} 6.3$ is due to the buffer capacity of carbonic acid ( $\left.\mathrm{p} K_{\mathrm{a}}=6.354\right)$ (Chem. Soc. Japan, 1982) that is dissolved in the solution.

Figure 8 shows the relation between the concentration of acetic acid, $c_{\mathrm{A}}$, and the maximum value of buffer capacity, $\left(\beta-\beta_{\mathrm{W}}\right)_{\max } / 0.576$. Straight line having a slope of 1.0 was obtained. The concentration of acetic acid is obtained directly from the maximum value of the buffer capacity.

The trial device was applied to an actual food study; the buffer capacity of green tea extract was measured. One gram (reduced to the dry state) of green tea was extracted with 50 $\mathrm{ml}$ of water at $60^{\circ} \mathrm{C}$ within $10 \mathrm{~min}$.

Figure 9 shows the buffer capacity curves (solid lines) of

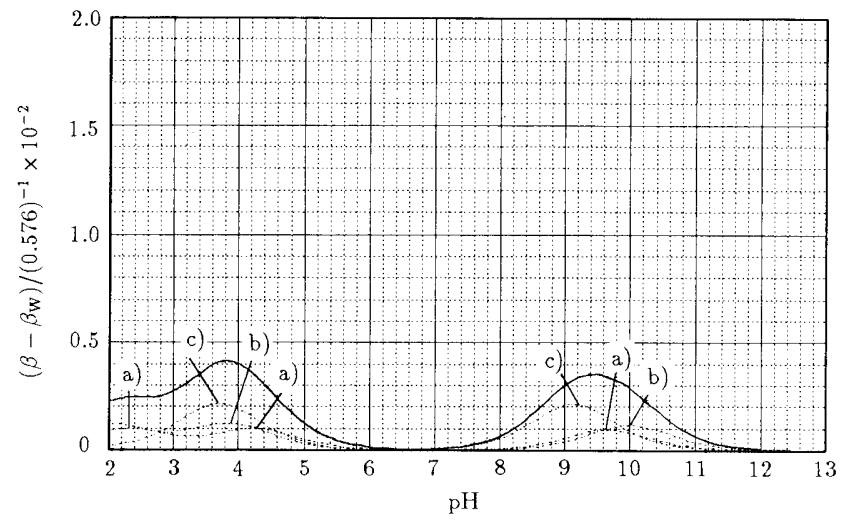

Fig. 10. Simulation curves of amino acids in tea extract. a) Glutamic acid $0.139 \mathrm{mg} \mathrm{ml}^{-1}$, b) aspartic acid; $0.154 \mathrm{mg} \mathrm{ml}^{-1}$, c) arginine; $0.371 \mathrm{mg} \mathrm{ml}^{-1}$.

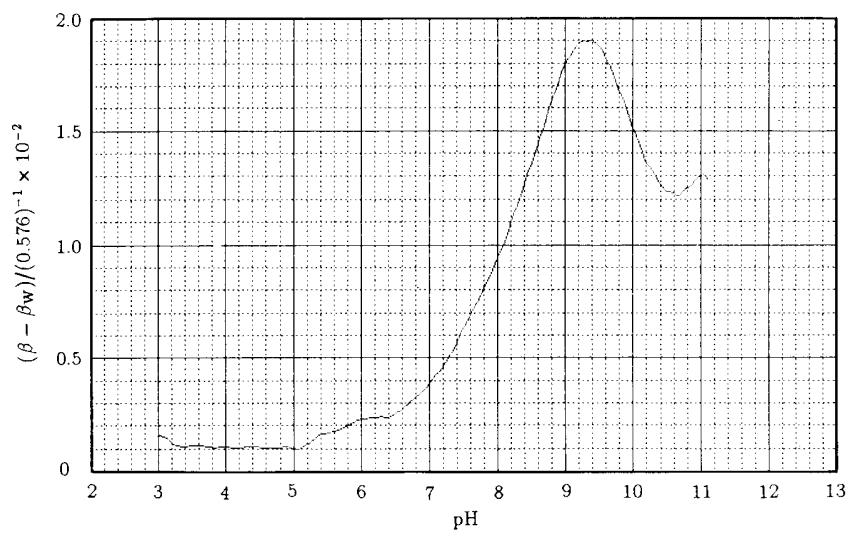

Fig. 11. Buffer capacity curves of catechins. Concentration: $5.87 \mathrm{mg} \mathrm{ml}^{-1}$.

the green tea extracts that were extracted at $60^{\circ} \mathrm{C}$ for $30 \mathrm{~s}, 5$ $\mathrm{min}$ and $10 \mathrm{~min}$. The curves show two broad peaks at nearly $\mathrm{pH} 3.7$ and 9.3, and the height of the peaks increased with increasing extraction time. In the figure, the dotted lines are the curves fitted by multivariate analysis (Lawson \& Hanson, 1974; Leggett, 1977) and the component curves (1-6) of the fitted curve for extraction for $30 \mathrm{~s}$.

In general, components in the green tea from different sources vary in the amounts of certain components; however, the values for the soluble components shown in Table 1 (Nakagawa et al., 1981; Kato, 1993) are referred to our experiment.

The $\mathrm{p} K_{\mathrm{a}}$ values of Glu, Asp, and Arg are known (Chem. Soc. Japan, 1982); therefore, the simulated curves of the buffer capacity of these amino acids can be pictured from the data of the analytical values and are shown in Fig. 10. The synthesized curve of these amino acids shows the same height for the peaks of the carboxyl group on the acid side ( $\mathrm{pH} 3.9$ ) and the amino group on the alkaline side $(\mathrm{pH} 9.5)$. The buffer capacity curves of catechins and theanine that were prepared from tea leaves show a peak at $\mathrm{pH} 9.4$ for catechins and at $\mathrm{pH}$ 8.9 for theanine and are shown in Figs. 11 and 12, respectively. Caffeine does not show any peaks of buffer capacity in the range of measured $\mathrm{pH}$.

The main organic acids in tea extract are oxalic and citric acids. The $\mathrm{p} K_{2}$ is 4.27 for oxalic acid, $\mathrm{p} K_{1}$ is $3.13, \mathrm{p} K_{2}$ is 4.76 and $\mathrm{p} K_{3}$ is 6.40 for citric acid, the values taken from a 


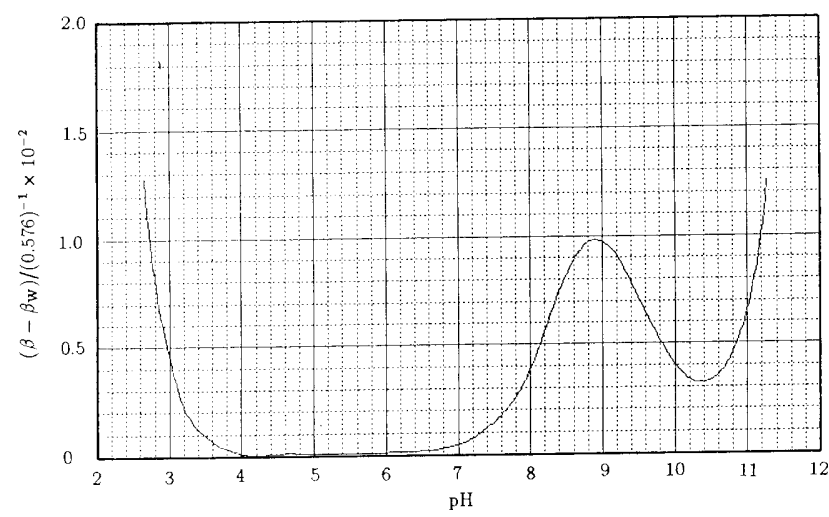

Fig. 12. Buffer capacity curves of theanine. Concentration: $1.74 \mathrm{mg} \mathrm{ml}^{-1}$.

chemical table (Chem. Soc. Japan, 1982). By simulation using the above values, the buffer capacity curves of organic acids in tea extract can be pictured as shown in Fig. 13. The figure shows a peak at nearly $\mathrm{pH} 4.3$, and the height of the peak is about 4 times that for the carboxylic groups of amino acids that are shown in Fig. 10.

The buffer capacity curves of the tea solution as shown in Fig. 9 might be at least the sum of the buffer capacity curves of the above components. Accordingly, the shoulder at about pH 3.7 in Fig. 9 may be mainly due to organic acids and the carboxylic groups of amino acids, and the peak at about $\mathrm{pH}$ 9.3 may be contributed by catechins, theanine and the amino groups of amino acids.

The peaks of the component curves of 2, 3, 4 and 5 may correspond to organic acid at $\mathrm{pH} 4.0$, theanine at $\mathrm{pH} 8.7$, catechins at $\mathrm{pH} 9.4$ and 10 , respectively.

It is difficult, however, to discuss component curves 1 and 6 , because the accuracy of the subtraction of the buffer capacity of water from that of the sample greatly decreases with the lower and the higher $\mathrm{pH}$, so that the component curves of 1 and 6 in the figure were omitted.

\section{Conclusions}

The trial device using a microcomputer for buffer capacity measurement has the following merits:

1) by subtracting the buffer capacity curve of water from that of the samples, it becomes possible to evaluate buffer capacities below $\mathrm{pH} 4$ and above $\mathrm{pH} 10$.

2) the buffer capacity can be measured at low concentration, such as $10^{-4} \mathrm{~mol} l^{-1}$, which is not feasible with equipment of the analog type.

3) from known $\mathrm{p} K$ values, buffer capacity curves can be easily obtained by simulation as shown for the green tea solution.

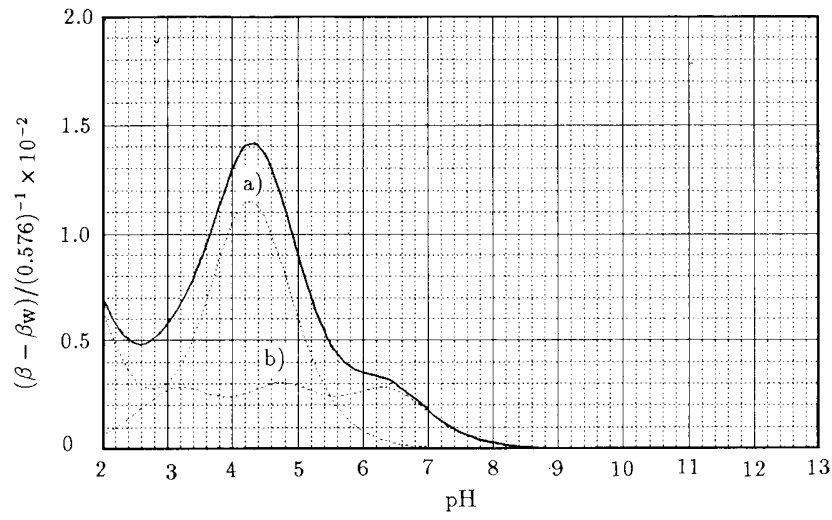

Fig. 13. Simulation curves of organic acids in tea extract. a) Oxalic acid; 1.03 $\mathrm{mg} \mathrm{ml} \mathrm{m}^{-1}, \mathrm{~b}$ ) citric acid; $0.51 \mathrm{mg} \mathrm{ml}^{-1}$, and solid line; synthesized curve of a) and b).

4) this device can be applied widely for ion dissociation equilibrium reactions.

\section{References}

Barrow, G.M. (1974). In "Physical Chemistry for the Life Sciences." McGraw-Hill, New York.

Chem. Soc. Japan (ed.). (1982). In "Hand Book of Chemistry." Maruzen, Tokyo.

Gordon, W.E. (1982). Data analysis for acid-base titration of an unknown solution. Anal. Chem., 54, 1595-1601.

Kato, M. (1993). Personal communication. Fac. Education, Kagawa Univ., Takamatsu, Japan.

Lawson, C.L. and Hanson, R.J. (1974). In "Solving Least Squares Problems." Prentice-Hall, Englewood Cliffs, New Jersey.

Leggett, D.J. (1977). Numerical analysis of multicomponent spectra. Anal. Chem., 49, 276-281.

Miyagawa, K. and Namba, A. (1988). Buffer capacity curves of cow's milk. J. Jpn. Soc. Food Sci. Tech., 35, 417-422.

Miyagawa, K., Yamamoto, E. and Namba, A. (1989). Buffer capacity curves of cow's milk (part II). J. Home Econ. Jpn., 40, 81 I-814.

Nakagawa, M., Anan, T. and Ishima, N. (1981). The relation of green tea taste with its chemical make-up. Stud. Tea, 17, 69-122.

Perrin, D.D. and Dempsey, B. (1974). In "Buffers for $\mathrm{pH}$ and Metal Ion Control." Chapman and Hall, London.

Savitzky, A. and Golay, M.J.E. (1964). Smoothing and differentiation of data by simplified least squares procedures. Anal. Chem., 36, $1627-1639$

Tsuji, K. (1982a). Buffer capacity curves of seasonings. J. Jpn. Soc. Biosci. Biotech. Agrochem., 56, 769-775.

Tsuji, K. (1982b). A recording device for buffer capacity curves. Technical Report and TOA News, No. 286. TOA Denpa Co., Tokyo.

Tsuji, K. (1982c). $\beta$-Titrator, a device for direct recording of buffer capacity curves: I. Theory and apparatus. Agric. Biol. Chem., 46, $677-682$.

Tsuji, K. (1983). Buffer capacity curves and foods. J. Chem. Biol. Jpn., 21, $757-762$.

Tsuji, K. and Takeo, T. (1983). Buffer capacity curves of green tea. $J$. Jpn. Soc. Food Sci. Tech., 57, 461-463. 